\title{
Home country
}

\section{supportiveness/unfavorableness and outward foreign direct investment from China}

Article

Accepted Version

Gaur, A. S., Ma, X. and Ding, Z. (2018) Home country supportiveness/unfavorableness and outward foreign direct investment from China. Journal of International Business Studies, 49 (3). pp. 324-325. ISSN 1478-6990 doi: https://doi.org/10.1057/s41267-017-0136-2 Available at https://centaur.reading.ac.uk/77593/

It is advisable to refer to the publisher's version if you intend to cite from the work. See Guidance on citing.

To link to this article DOI: http://dx.doi.org/10.1057/s41267-017-0136-2

Publisher: Palgrave Macmillan

All outputs in CentAUR are protected by Intellectual Property Rights law, including copyright law. Copyright and IPR is retained by the creators or other copyright holders. Terms and conditions for use of this material are defined in the End User Agreement. 


\section{CentAUR}

Central Archive at the University of Reading

Reading's research outputs online 


\title{
HOME COUNTRY SUPPORTIVENESS/UNFAVORABLENESS AND OUTWARD FOREIGN DIRECT INVESTMENT FROM CHINA
}

\author{
Ajai S. Gaur \\ Associate Professor \\ Department of Management and Global Business \\ Rutgers Business School \\ Rutgers University \\ 1 Washington Park, Newark, NJ 07102 \\ Tel: 1 732-646-5094, Fax: 1 973-353-1664 \\ Email: ajai@business.rutgers.edu \\ Xufei Ma* \\ Associate Professor \\ Department of Management \\ CUHK Business School \\ The Chinese University of Hong Kong \\ Shatin, New Territories, Hong Kong SAR \\ Tel: +852-39437799 \\ E-mail: xufei@cuhk.edu.hk \\ Zhujun Ding \\ Lecturer \\ School of Leadership Organizations and Behaviour \\ Henley Business School \\ University of Reading \\ Whiteknights, Reading, United Kingdom \\ Phone: +44 (0) 1183788554 \\ E-mail: zhujun.ding@henley.ac.uk
}

*Corresponding author.

Acknowledgements: We are grateful to the area editor, Professor Mariko Sakakibara and the anonymous reviewers for their constructive comments and suggestions that have helped significantly improve the paper. We also acknowledge support from the GRF Grants by HKSAR (No.14501714; No.14504715).

\section{Citation:}

Gaur, A. S., Ma, X., \& Ding, Z. 2018. Home country supportiveness/ unfavorableness and Outward Foreign Direct Investment from China. Journal of International Business Studies, forthcoming. 


\title{
HOME COUNTRY SUPPORTIVENESS/UNFAVORABLENESS AND OUTWARD FOREIGN DIRECT INVESTMENT FROM CHINA
}

\begin{abstract}
What drives the outward foreign direct investments (OFDIs) by emerging market firms (EMFs)? Drawing on a strategy tripod framework, this article proposes a theoretical model to predict OFDI by EMFs from China. Specifically, we use institution- and industry-based views to examine two facets of home country environment, namely the supportiveness from home government and unfavorableness from home industry, as important determinants of OFDI, and compare the relative strength of these effects. Further, we use resource-based view to argue that the effect of the home country environment is contingent on the international experience portfolios of EMFs.
\end{abstract}

Keywords: home country environment, outward FDI, emerging market firms, international experience 


\section{INTRODUCTION}

What drives emerging market firms (EMFs) to make outward foreign direct investments (OFDIs)? This question is a key issue for international business (IB) given that 9 of the 20 countries with the largest OFDIs are emerging markets (EMs) (UNCTAD, 2015). It is also of theoretical interest, in that recent trends in the internationalization of EMFs are somewhat inconsistent with traditional views (CuervoCazurra, 2012; Luo \& Tung, 2017). For example, the conventional view that firms make use of ownership-specific advantages to internationalize in search of markets, efficiency, and resources (Dunning, 1993) does not completely explain the internationalization of EMFs. At the same time, with an overwhelming focus on firm-level drivers, the asset-exploitation and asset-seeking arguments (Makino, Lau, \& Yip, 2002) often do not pay adequate attention to the home environment. Moreover, though scholars have adopted multiple perspectives to explain the internationalization of EMFs, the findings remain fragmented and disconnected.

Considering the complexity of EMs and EMFs, an eclectic perspective seems more suited to explaining their internationalization behavior. We thus use a strategy tripod framework (Peng, Wang, \& Jiang, 2008), which asserts that IB activities should be viewed through multiple lenses: institution-based views (Peng et al., 2008), industry-based views (Porter, 1990), and resource-based views (RBV; Barney, 1991). Our use of the strategy tripod framework responds to calls to understand the environmental drivers of EMFs' OFDIs by going beyond firm-level, ownership-specific advantages and disadvantages as determinants of OFDI (Luo \& Tung, 2007; Ramamurti, 2012). 
We focus on two disparate home-country environmental forces that affect the OFDI activities of EMFs. First, EM governments encourage local firms to pursue international expansion through a variety of incentives and measures (Luo, Xue, \& Han, 2010). Such support helps EM firms overcome the liability of foreignness and pursue international expansion, despite their lack of ownership-specific advantages (Luo \& Tung, 2007). Second, EMFs often face unfavorable industry environments at home, forcing them to escape their home markets to pursue international opportunities (Cuervo-Cazurra, 2012). Homecountry environmental factors can make some industries unattractive by affecting the availability and quality of factor inputs and the competitive landscapes of domestic markets (Singh, Pattnaik, Gaur, \& Ketencioglu, 2018). Because firms undertake internationalization not only to benefit from support from their home governments but also to escape stifling industry environments in their home markets (Lewin \& Witt, 2007), we examine government supportiveness and industry unfavorableness as potential drivers of OFDI activities. By adopting both institution- and industry-related home environmental factors as a baseline logic, we also determine how resource-based factors and firm-specific capabilities condition the relationships between environmental factors and OFDI activities.

We thus make three important contributions to IB research. First, we advance understanding of the drivers of OFDI activities of EMFs by recognizing that even though the two environmental forces of “support" and "escapism" coexist (Lewin \& Witt, 2007; Luo et al., 2010; Singh et al., 2018), literature tends to examine them in isolation. Our paper is among the first to redress this shortcoming by arguing that the OFDI decisions of EMFs are driven by the simultaneous presence of government supportiveness (Peng et al., 2008) and industry unfavorableness (Khanna \& Palepu, 1997; Lewin \& Witt, 2007). We 
further compare the relative strengths of these two effects.

Second, we advance understanding of how organizational factors condition the effects of environmental factors on firm strategies in the IB context. Although institutional and industry factors matter, it is of theoretical importance to examine the conditions and the ways in which their effects vary. We expand the conceptualization of international experience portfolios to argue that firms can gain international experience in foreign markets by exporting and in domestic markets by engaging in inward internationalization (Gaur \& Delios, 2015; Luo \& Tung, 2007). By examining these organizational contingencies and providing insights into the boundary conditions of home-country environmental effects, we contribute to research on the drivers of OFDI activities of EMFs.

Third, we make an important empirical contribution by introducing managerial cognition to the study of the effects of the home country environment on firms' international strategies (Wan \& Hoskisson, 2003). Typically, international expansion decisions take place at the top management level; they pose informational and cognitive challenges for senior managers. From a management perspective, perception is more important than objective reality with regard to links between external environments and firms' strategic decisions. With our research design, we directly measure perceived levels of government supportiveness and industry unfavorableness. Although firms may face the same policy conditions and industry parameters, they likely experience different impacts from these external environmental forces. The key differential is managerial cognition: managers differ in their perceptions of the supportiveness and favorableness of their external environments (Daft \& Weick, 1984; Weick, 1979). These perceptions often include unobservable factors, such as a firm's readiness to benefit or suffer from external factors. 
Therefore, our direct measurement of managerial perception is an important empirical improvement.

Figure 1 presents the broad theoretical framework of our study.

----------Insert Figure 1 about here----------

We test our theoretical model in the context of Chinese firms. China provides an ideal setting to test our theory because it features a proactive government, competitive domestic markets, intensive interactions between foreign and Chinese firms, and aggressive internationalization of domestic firms (Buckley et al., 2007; Child \& Rodrigues, 2005). We adopt a mixed-methods design by combining the empirical findings of a survey with insights from interviews of senior managers (Creswell \& Clark, 2011). This approach allows us to gain a better understanding of this emerging phenomenon in a complex context, which in turn advances theory (Birkinshaw, Brannen, \& Tung, 2011; Weick, 1979).

\section{THEORY AND HYPOTHESES}

\section{Strategy tripod perspective on OFDI by EMFs}

The strategy tripod framework acknowledges the importance of the external environment as a determinant of firm strategy and competitiveness (Peng et al., 2008). The genesis of the framework is the recognition that two other dominant frameworks - the industry-based view (Porter, 1990) and the RBV (Barney, 1991) - ignore the institutional contexts in which firms are embedded and that shape their behavior (Scott, 2001). Institutions set up the "rules of the game" (North, 1990), thereby affecting firms' strategic choices in significant ways. In particular, in emerging economies, there is wide variance in the nature, type, and behavioral impact of institutions. By acknowledging this variation, scholars emphasize the importance of home country environments to firms' strategic behavior and success (North, 1990; Scott, 2001). 
Researchers focus on different components of the strategy tripod framework as determinants of internationalization. For example, Gaur, Kumar, and Singh (2014) argue that home-country institutional environments and firm resources - two of the three legs of the tripod framework —individually and jointly affect firms' likelihood of shifting from exports to more aggressive forms of internationalization such as OFDI. Wan and Hoskisson (2003) focus on the home environment, classifying it according to its degree of support for international expansion. They argue that firms in more munificent environments derive greater benefits from internationalization than do those in less munificent environments. Moreover, constraints on firms in less munificent environments act as catalysts to encourage them to expand abroad; Luo and Tung (2007) refer to SABMiller's expansion abroad to escape a stifling environment in its home market of South Africa. Thus, OFDI is a response by EMFs to conditions in their home environments.

Table 1, which includes key studies identified by a systematic review of literature (Gaur \& Kumar, 2018), depicts the importance of the home country environment to OFDI. Prior literature does not differentiate between the supportiveness and unfavorableness of home environments. For example, there has been a gradual push for Chinese firms to internationalize, initially from the "go global" policy of the Chinese government and more recently from increased domestic competition (Buckley et al., 2007). As EMFs undergo reforms, competition in domestic markets likely increases, thereby pushing firms to become more international; EMFs may use international expansion as a springboard to acquire the strategic resources they need to compete in their home markets (Luo \& Tung, 2007, 2017).

----------Insert Table 1 about here-----------

Clearly, the effect of home market environment is complicated. Managers may perceive their 
home environments as supportive to some aspects but constraining to others, such as to the domestic operations of local firms (Boisot \& Meyer, 2008). The two conditions are not the two ends of the same spectrum; they capture different dimensions of the home country environment (North, 1990) and affect the international expansion of EMFs through different mechanisms. By taking both institution-based and industry-based views into account, we identify two divergent aspects of the home environment: government supportiveness and industry unfavorablenesss. We rely on managerial cognition and the micro-foundations of organizational behavior to argue that managers possess differing cognitive frames that help them make sense of external environments (Daft \& Weick, 1984). Even when firms share the same external environment, individual managers interpret the environment differently; their interpretations shape the strategic choices they make (Felin, Foss, Heimeriks, \& Madsen, 2012). In the context of our study, managerial perception is a particularly important factor, given China's relative lack of transparency about government-firm relationships and lack of clarity about regulatory frameworks. In China, even though clear policies are in place, implementation of the policies may vary according to the informal networks of managers. Thus, even though all market players face the same external environment, some managers may perceive it as favorable while others do not.

\section{Perceived government supportiveness}

State capitalism is on the rise; governments, particularly in emerging markets, are actively encouraging domestic enterprises to establish footholds in international markets (Economist, 2012). With regard to policy inducements for internationalization in China, Buckley et al. (2007) identify five evolutionary stages: cautious internationalization as a means of opening up, government encouragement to establish 
foreign affiliates, expansion and regulation, implementation of the "go global" policy, and aggressive internationalization in the period following establishment of the World Trade Organization. Given the dominant role of state control in the Chinese economy (Buckley et al., 2007), government support is likely to have profound effects on firm internationalization.

Government support is beneficial only if key decision makers perceive it to be. Microfoundations literature argues for the importance of individual actors' perceptions in organizational decision making (Felin et al., 2012). Managerial perception consists of noticing, encoding, interpreting, and refocusing effort and time (Ocasio, 1997). Different organizational actors interpret signals from the environment differently. Therefore, managerial perceptions of supportiveness, rather than actual supportiveness, determine their actions; they affect structured decision making, by infiltrating both formal and informal organizational structures (Yu, Engleman, \& Van de Ven, 2005). These perceptions also change decision makers' mental schema and frameworks, making them more sensitive to environmental influences (Yu et al., 2005). In the context of China, which is transforming from a planned to a marketbased economy, traditional control by central and regional government agencies lingers and the influence of government ideology continues to be important.

There are several reasons managers likely pursue OFDI when they perceive they have government support. First, they may perceive government policies to be helpful in facilitating international expansion (Ma, Ding, \& Lin, 2016; Wang, Hong, Kafouros, \& Wright, 2012). Supportive foreign exchange management policies make it easier for firms to obtain needed foreign currency, and there are fewer bureaucratic hassles and more OFDI approvals. In China, the perception is that the 
government fosters the establishment of internationally competitive firms (Gaur, Malhotra, \& Zhu, 2013), which encourages firms to take OFDI risks. If managers perceive government policies as favorable to OFDI activities, they are more likely to take the necessary OFDI steps, including liaising with government officials to seek support for internationalization initiatives.

Second, governments can help firms overcome ownership-specific disadvantages by providing resources such as subsidies, tax benefits, privileged access to raw materials, and low-cost capital (Buckley et al., 2007). By doing so, governments compensate firms for the institutional voids that inhibit them from developing ownership-specific advantages in domestic markets. If managers have confidence that governments will help them access critical resources for international expansion, they are less likely to be deterred by a lack of ownership-specific advantages.

Third, governments can help domestic enterprises reach scales of economic viability that allow them to succeed in international markets. Gaur et al. (2013) argue that the Chinese government encourages mergers and acquisitions, even in unrelated domains, to create large enterprises. For example, in 2006, China National Bluestar acquired the silicone and sulfide businesses of the French company Luo Sulphadiazine, making it the third-largest producer of organic silicone in the world; in the same year, it acquired Adisseo, the world's largest producer of animal nutrition supplements (Tang, 2007). Once a firm achieves a dominant competitive position in its domestic market, it becomes a source of competitive advantage for foreign expansion; managers perceive and expect governments to help them achieve economies of scale that are critical for success in international markets.

In summary, managerial perceptions of home-country government supportiveness, indicated by 
policy support, resource access, and facilitation of economies of scale, encourage firms to engage in

OFDI. Accordingly, we expect a positive relationship:

Hypothesis 1: The perceived supportiveness of home country government for OFDI will be positively associated with an EMF's degree of OFDI.

\section{Perceived industry unfavorableness}

Even if EMFs perceive their home country governments to be supportive, their home country

environments may create perceived hardships (Khanna \& Palepu, 1997). Luo and Tung (2007) argue that domestic market constraints are key motivations for firms to expand abroad; that is, internationalization allows EMFs to exit unfavorable domestic markets (Boisot \& Meyer, 2008). In addition, EMFs expand abroad to gain access to resources and capabilities they do not have in their home markets (Makino et al., 2002). These resources help EMFs internationalize but also compete with local and foreign firms in their home markets (Mathews, 2006). Thus, OFDI is often a means to escape difficult conditions in home markets and gain access to strategic resources that are not available domestically.

Several factors make it difficult for firms to operate domestically, including competition by local and foreign players in the home industry and shortages of strategic resources such as technology and talent. On the one hand, as governments in emerging economies open up to competition, there is an influx of domestic and foreign firms (Wiersema \& Bowen, 2008; Yiu, Lau, \& Bruton, 2007). Foreign firms, with their superior resources and capabilities, may even crowd out domestic firms (Kosova, 2010). Individual managers may perceive foreign firm threats differently. Some consider foreign firms' presence, and the heightened competition that results, helpful for creating an ecosystem for future success, but 
others may believe that competition threatens their firms' survival. For the latter, the search for alternative markets becomes an unavoidable strategic choice (Xia, Ma, Lu, \& Yiu, 2014). In the case of EMFs, the search leads to international markets that provide more opportunity for arbitrage (Ghemawat, 2007). Luo and Wang (2012) find that for Chinese firms, increased competitive pressure in home markets relates positively to the timing and extent of OFDI.

On the other hand, as domestic competition intensifies, EMFs try to augment their cost-based advantages (Rui \& Yip, 2008) by moving up the value chain and acquiring proprietary technology, brand names, and other resources (Luo \&Tung, 2017). These resources and capabilities often are not available in the home markets of EMFs; because of path dependence and time-compression diseconomies in the capability development process, it is difficult for EMFs to develop them in-house (Dierickx \& Cool, 1989). If managers believe their home country environments are not munificent enough to provide needed resources, they must explore other environments in which their firms can obtain the resources they need to develop and maintain their competitive advantage (Wan \& Hoskisson, 2003). Using a springboard theory of firm internationalization, Luo and Tung (2007) argue that EMF managers aggressively expand to foreign markets in search of strategic resources that they later use to strengthen their competitive positions in home markets. Similarly, Mathews (2006) proposes the learning-linkage-leverage framework, which suggests that latecomer multinational corporations (MNCs) from emerging markets are pulled into developed economies to acquire knowledge related assets.

In summary, perceptions of industry unfavorableness, indicated by heightened competition or unavailability of resources in domestic markets, force EMFs to expand to foreign markets. Accordingly, 
we expect a positive relationship:

Hypothesis 2: Perceived unfavorableness of the home country industry is positively associated with an EMF's degree of OFDI.

\section{Relative strength of supportiveness and unfavorableness}

Given the mechanisms whereby perceived supportiveness and perceived unfavorableness affect EMFs' degree of OFDI, we proceed to examine the relative strength of the two effects. We argue that the positive effect of government supportiveness is stronger than the escapism effect of unfavorable industry conditions on OFDI, for two reasons. First, according to an institutional perspective, governments are the controllers, regulators, and adjudicators of business sectors (Boddewyn, 1988). In China, governmental promotion of OFDI is a legitimate political action that compensates for EMFs' competitive disadvantages and organizational deficiencies (Luo et al., 2010). Government actions are targeted at minimizing the negative effects of domestic market conditions. For example, the Chinese government encourages domestic firms to merge so that they can compete with larger foreign firms (Gaur et al., 2013). It also provides financing for foreign expansion (Luo et al., 2010). According to an institutional perspective, governments significantly shape business activities and behaviors in societies in which there is a high level of business-government interdependence (Boddewyn, 1988).

Second, firms tend to attribute less importance to unfavorable factors, particularly when it is possible for them to reduce the negative consequences. In China, firms can successfully lobby against foreign firms and get support from local or central governments to maintain their competitive positions within the domestic market. Although China transforms to a market-based economy, the government thus 
continues to play a visible role, minimizing or compensating for unfavorable domestic industry conditions.

As a result, perceptions of government supportiveness likely play a greater role in determining EMFs' degree of OFDI than perceptions of the unfavorableness of the domestic industry.

Hypothesis 3: The effect of perceived supportiveness is stronger than the effect of perceived unfavorableness.

\section{Contingent effects of international experience}

In accordance with the RBV, we argue that EMFs' previous international experience forms a critical resource base for their pursuits of international markets (Gaur et al., 2014). Firms can gain international experience through outward activities such as exporting abroad (Singh, 2009) and through inward activities such as cooperating with foreign firms at home (Xia et al, 2014). However, these two types of international experience differ qualitatively; they likely have differing impacts on the relationships between home country environments and OFDI.

Export experience. Exporting is the most significant EMF internationalization strategy (Child \& Rodrigues, 2005). According to the Uppsala model, firms start their foreign operations using traditional modes, such as exporting, then gradually move to more intensive, demanding operational modes, such as OFDI (Johanson \& Vahlne, 2009). The experience they gain through exporting helps them when they decide to pursue international markets more aggressively through OFDI (Child \& Rodrigues, 2005; Gaur et al., 2014); for example, EMFs with significant exporting operations are exposed to advanced international standards and a large number of customer segments with varying tastes and preferences. Such exposure helps EMFs tailor their strategies and product offerings when they expand. 
Export experience is likely to augment the positive effect of the home country environment on OFDI. Firms with strong government support for internationalization may seek OFDI opportunities. Having a presence in foreign markets through exporting makes firms familiar with customer expectations and connects them with other firms in the value chain (Gaur et al., 2014). It allows them to understand the extent and nature of competition and recognize other challenges of operating in foreign markets. With a better understanding of opportunities and challenges, firms can lobby home governments and seek targeted support for OFDI activities. Although home governments in EMs are often willing to help domestic firms, they lack a clear understanding of the best ways to do so. Government support may take the form of financial guarantees and faster approvals or even lobbying of foreign governments to protect the interests of home-market firms (Luo et al., 2010). Accordingly, we expect export experience to positively moderate the relationship between favorable home country government support and OFDI.

Hypothesis 4a: The relationship between perceived supportiveness of home country government and degree of OFDI is stronger for firms with higher levels of export experience.

Export experience also helps firms when they expand abroad to escape harsh domestic conditions. Heightened competition in home markets often pushes firms to expand abroad in search of market arbitrage opportunities. With higher levels of exporting experience, firms have a better understanding of the extent and nature of foreign competition (Child \& Rodrigues, 2005); they can choose markets that allow them to exploit their home-market competitive advantages without being subject to competitive pressures. Moreover, exporting experience helps firms identify markets that have the strategic resources 
they need to augment their home-market competitive advantages (Kang \& Jiang, 2012). Without sufficient export experience, EMFs that face harsh conditions in their home markets may not even know of potential opportunities in foreign markets. Accordingly, we expect export experience to positively moderate the relationship between perceived unfavorableness of the home-country industry environment and OFDI.

Hypothesis 4b: The relationship between perceived unfavorableness of home country industry and degree of OFDI is stronger for firms with higher levels of export experience. Inward internationalization. Inward internationalization is the experience that EMFs gain through connections with foreign firms in domestic markets (Gu \& Lu, 2011). They often engage with developed market MNCs in joint ventures, licensing, co-production, and other cooperative arrangements in their home markets (Welch \& Luostarinen, 1993; Zhou, Wu, \& Luo, 2007); MNCs engage with local firms to exploit the cost-factor differentials offered by emerging markets (Nuruzzaman, Gaur, \& Sambharya, 2017). Local firms benefit from such arrangements by receiving regular sources of revenue, and sometimes even technology, to improve their production processes (Mathews \& Zander, 2007).

There are two mechanisms through which OFDI might be affected by a negative interaction between inward internationalization and perceived government support. First, inward internationalization likely diminishes the benefits of favorable government support. EMFs with intentions to go abroad can acquire the resources needed for foreign expansion from foreign partners in their domestic markets, rather than from governments (Gu \& Lu, 2011). For example, foreign market information and in some cases access that government agencies provide might be inferior to that from foreign players. Foreign players 
may extend domestic market relationships to foreign markets, thereby giving EMF partners additional market access. Greater inward experience with foreign firms provides these alternate avenues, and support infrastructure that they need to pursue international expansion, and reduces the need for government support.

Second, inward internationalization reduces the value of government supportiveness, because OFDI itself becomes a less attractive option. The stable revenues generated through domestic partnerships with foreign MNCs makes EMFs complacent and less likely to seek foreign opportunities. Policy benefits, such as easier access to foreign currency and quicker administrative approval, have no roles to play in OFDI if firms have little intention to expand abroad. Moreover, according to the springboard perspective, EMFs go abroad in search of resources and technology that can help them compete in their home markets (Luo \& Tung, 2007; 2017). Accordingly, EMFs with high levels of inward internationalization may not have strong incentives to seek such resources in international markets; they can obtain resources and technology from foreign MNCs in their home markets. In summary, home government supportiveness is less likely to help firms expand abroad if they have high levels of inward internationalization.

Hypothesis 5a: The relationship between perceived supportiveness of home country government and degree of OFDI is weaker for firms with higher levels of inward internationalization.

The logic of escapism also is less applicable if EMFs enjoy the benefits of cooperation with MNCs in domestic markets. With higher levels of inward internationalization, EMFs have stable sources of resources and information that they can use to mitigate industry unfavorableness in their home country 
environments. For example, EMFs often have cooperative agreements with foreign MNCs that use local operations as nodes of their international networks ( $\mathrm{Lu} \& \mathrm{Ma}, 2008$ ). The connections with the foreign MNCs reduce the need to go abroad in search of resources and technology.

Moreover, inward internationalization allows firms to participate in international markets through global value chains without being directly involved in foreign markets. In evolving global factory configurations (Buckley, 2009), firms no longer operate in silos defined by organizational boundaries. Instead, they operate as modules in the global orchestration of value chains (Kedia \& Mukherjee, 2009; Mukherjee, Gaur \& Dutta, 2013). In such environments, unfavorable domestic environments may be less relevant, even for firms that seek market opportunities abroad, if the firms have connections with foreign firms that are global orchestrators of their respective industry domains. For example, many firms around the world participate in the global value chains orchestrated by Boeing and Airbus; they participate in international markets without having an actual physical presence in those foreign markets (Gaur \& Mudambi, 2016). Thus, the push effect of unfavorable conditions of domestic competition likely is diminished for EMFs with higher levels of inward internationalization.

Hypothesis 5b: The relationship between perceived unfavorableness of home country industry and degree of OFDI is weaker for firms with higher levels of inward international experience.

\section{METHODS}

\section{Sample and data collection}


We followed a mixed-methods approach, which combines quantitative and qualitative analysis in a single study (Creswell \& Clark, 2011). We used an explanatory sequential design, which begins with quantitative analysis, explained by a qualitative follow-up. This type of design, often used in health science, explains the underlying mechanisms of quantitative results in greater depth (Creswell \& Clark, 2011). We began the study by reviewing relevant literature. Then we collected quantitative data from a detailed, reliable survey of Chinese firms with OFDIs. Finally, we obtained qualitative data from interviews with four managers of four firms and derived our conclusions by combining theoretical arguments with qualitative evidence.

There are three reasons China represents a suitable empirical setting for testing our hypotheses. First, even though its domestic industry has not been particularly supportive of growth aspirations, the Chinese government proactively encourages Chinese firms' "going-abroad" strategies (Buckley et al., 2007; Luo, 2005). Second, China is the largest FDI host and home country among EMs (Sauvant \& Chen, 2013). Third, many Chinese firms engage in inward and outward international connections with their foreign counterparts (Child \& Rodrigues, 2005; Luo \& Tung, 2007), making the context theoretically and practically relevant.

The survey was conducted in 2011 by the staff from the local branches of our Chinese survey partner, which is a well-established, nation-wide organization in charge of the promotion of foreign trade and foreign investment. This survey partner's members include enterprises and organizations representing various sectors in China, and it has published a series of high-quality and influential policy reports derived from its previous surveys. Hoskisson, Eden, Lau, and Wright (2000) suggest that in emerging 
economies, collaboration with local organizations provides a key way to obtain reliable and valid information.

We first developed the survey instrument in English, and then translated it into Chinese with the assistance of two independent translators. We subsequently translated the Chinese version back to English to ensure conceptual equivalence. Using the list of 68,000 Chinese firms that are members of our survey partner organization, the survey team selected a random, diverse, and representative sample of 350 firms from 69 cities and 16 provinces/municipalities in the east, middle and west of China, representing 12 main industries and 46 sub-industries. Experienced interviewers from our Chinese survey partner's local branches conducted on-site interviews, with the rationale that in emerging economies, face-to-face interactions are more likely to generate valid information (Zhou, Yim, \& Tse, 2005). Respondents were CEOs and senior managers, directly involved in internationalization projects. The local interviewers' efforts resulted in the collection of 333 completed surveys. We excluded responses from firms that had no exports and OFDI, given that such firms would not be familiar with international operations and relative policies, leaving 251 firms with exports and OFDI. We further excluded responses that were missing values on key variables, such that our final sample consisted of 212 usable questionnaires. A comparison of the included firms (212 firms) with those excluded (121 firms) indicated no significant differences in terms of firm size $(\mathrm{t}(331)=-1.208, p=0.227)$ or firm age $(\mathrm{t}(331)=0.932, p=0.352)$.

\section{Dependent variable}

The dependent variable in our study is a firm's outward foreign direct investment (OFDI). We adopted Hitt, Hoskisson, and Kim's (1997) entropy approach, which is a measure of OFDI to account for the 
proportion of foreign subsidiaries to total subsidiaries and their global distribution. We calculated the entropy measure using the following equation:

$$
O F D I=\sum_{i}\left(F B_{i} \times \ln \left(1 / F B_{i}\right)\right]
$$

where $\mathrm{FB}_{\mathrm{i}}$ is foreign subsidiaries attributed to regional market $\mathrm{i}$, and $\ln \left(1 / \mathrm{FB}_{\mathrm{i}}\right)$ is the weight given to each regional market, or the natural logarithm of the inverse of its subsidiaries. We classified foreign markets into six regions: Europe, North America, Latin America, Africa, Asia, and Australasia.

By using an entropy approach, we could resolve some concerns related to existing measures of internationalization, such as ratios of foreign sales to total sales, foreign assets to total assets, foreign employees to total employees, or number of foreign subsidiaries to total subsidiaries (Sullivan, 1994). However, these measurements do not capture the breadth and depth of foreign investment, because they are unidimensional scales or assign all foreign markets the same importance (Hitt et al., 1997).

\section{Explanatory variables}

Perceived government supportiveness. Government supportiveness refers to the promotion policy and assistance provided by home governments for the international expansion of domestic firms (Luo \& Tung, 2007); it plays important roles in helping EMFs offset their ownership and location disadvantages in foreign markets, typically in the form of privileged access to raw materials, low-cost capital, subsidies, and other benefits (Buckley et al., 2007).

Using the Chinese OFDI promotion policies illustrated by Luo et al. (2010), as well as Chinesefirm interview data investigated by Voss, Buckley, and Cross (2010), we developed a measurement scale for perceived government supportiveness. Originally, the scale consisted of eight items: taxation support, 
financial policy support, foreign exchange-supporting policy, foreign rights and interests-guaranteeing policy, approval and commodity inspection-simplifying policy, industrial support, rights protection, and foreign investment information services, on a 7-point Likert scale. After rigorous explorative factor (EFA) and confirmative factor (CFA) analyses, we retained four items from the original scale: foreign rights and interests-guaranteeing policy, approval and commodity inspection-simplifying policy, foreign exchangesupporting policy, and foreign investment information services.

Perceived industry unfavorableness. Perceived industry unfavorableness relates to the availability of crucial factors and markets in the competitive environment of the home country (Castrogiovanni, 1991). Scholars have identified several factors that make domestic environments constraining to business, including home-industry competition (Yiu et al., 2007), foreign competition in domestic markets (Wiersema \& Bowen, 2008), and the availability of strategic resources such as advanced technology and human resources (Deng, 2009; Hitt et al., 1997; Luo \& Tung, 2007). According to extant literature, we developed a scale with 11 items on a 7-point Likert scale ( 1 = "strongly disagree," $7=$ "strongly agree"). After rigorous scale development using EFA and CFA, we narrowed the items on the scale of perceived industrial unfavorableness down to four: unavailability of advanced high-level talents, unavailability of advanced technology, competition from domestic firms in the home country, and competition from foreign multinational enterprises in the home country.

Export experience. We used two items to measure export experience: export intensity and export years (Gaur \& Lu, 2007). We measured export intensity as the ratio of export sales to total sales (Gao, Murray, Kotabe, \& Lu, 2010; Yiu et al., 2007), thereby indicating the extensiveness of export activities. 
Other authors have used this indicator to measure the outward international orientation of EMFs (e.g., Gaur et al., 2013). We measured export years as the natural logarithm of the number of years since the company's first export (Lu, Liu, Wright, \& Filatotchev, 2014).

Inward internationalization. Inward internationalization is the extent to which domestic firms take part in international activities using cooperative arrangements with foreign firms in their home countries (Welch \& Luostarinen, 1993; Zhou et al., 2007). We developed a measure of inward internationalization according to Zhou et al. (2007), which consisted of four items: extent of use of foreign capital, technology, joint venture, and production line or devices in home country, on a 7-point Likert scale.

\section{Control variables}

We controlled for several sources of heterogeneity that could affect OFDI decisions. First, we controlled for firm age, size, performance, ownership, and industry as important factors that affect firms' OFDIs. Older companies may have more resources for OFDI, so we controlled for firm age using the natural logarithm of the number of years since a firm was established. We also controlled for the number of employees as an indicator of firm size, because larger companies likely possess more resources for OFDI (Lu et al., 2014). We controlled for firm performance by measuring managerial perception of domestic sales as compared to competitors, which is similar to the relative market share of the firm. We controlled for ownership status using a variable that identified whether the firm was a state-owned enterprise (SOE). We used industry dummies in all models.

Second, we controlled for several factors related to firms' international strategies, which may 
enable OFDI. We controlled for the top management team's foreign experience using an indicator variable which took a value of 1 if there were overseas returnees in the top management team and 0 otherwise (Tihanyi, Ellstrand, Daily, \& Dalton, 2000). We controlled for technological capability by asking respondents, on a 7-point Likert measurement scale, whether technological capability influenced their firm's OFDI decisions (Knight \& Cavusgil, 2004). Foreign government support was controlled by measuring whether the firm could get support from the foreign government, on a 7-Likert measurement scale. We controlled for localization, because responding to local needs and culture helps multinational firms achieve local success (Cantwell, 2009; Luo \& Tung, 2007). To assess the firm's degree of localization, we used a five-item, 7-point Likert scale. The five items included learning and absorbing local business knowledge, studying local customer needs, developing local partnerships, empowering overseas managers to decide business scope, and empowering overseas managers to decide financial budgets and reviews. Finally, we controlled for the foreign experience of top management teams (TMTs) using a dummy variable that took a value of 1 if there were overseas returnees in the TMT and 0 otherwise (Tihanyi, Ellstrand, Daily, \& Dalton, 2000).

Third, we controlled for external environmental factors that may influence firms' OFDI strategies. Boisot and Meyer (2008) argue that the costs of domestic transactions, such as those across internal provincial boundaries, can be greater than those involved in international transactions. Therefore, we controlled for internal provincial boundaries using the regional protection index developed by Fan, Wang, and Zhang (2001). This index captures the development of each province in reducing regional protection (Fan et al., 2001). At the same time, regional average wage was controlled as the domestic labor cost 
might also impact the international strategy (Rugman \& Verbeke, 1992). The data come from the annual national statistical reports of the National Bureau of Statistics. Finally, to capture the effect of industry supportiveness, we constructed a variable that equals the ratio of the number of countries with supportive industries to the total number of countries in which a firm invests. We delineated supportive industries as those with investments that accord with the Chinese government's guidance for FDI to a given country in a given year (Lu et al., 2014). The data come from the Guidance Catalogue of Countries and Industries for Overseas Investment, a set of guidelines for Chinese FDI that inform firms' foreign entry decisions (Buckley, Clegg, Cross, \& Voss, 2010; Luo et al., 2010).

\section{Common method bias}

The information used to measure the dependent variable and the independent variables comes from different sources, minimizing the concerns for common method bias. We obtained data on the number of foreign subsidiaries launched in each region, as the base for calculating the dependent variable (an entropy measure of OFDI) from archival sources such as the annual reports. This information was further verified by our Chinese survey partner's local staff with the help from firm executives in charge of the finance/accounting. The other two independent variables, perceived government supportiveness on OFDI and perceived industry unfavorableness in the home market were assessed subjectively by the informant of the firm surveyed (i.e., CEO or a senior manager directly involved in the firm's internationalization). Moreover, one moderator (i.e., inward internationalization) was measured subjectively, and the export information related with the other two moderators (i.e., export intensity and export age) was objectively derived from archival data. We conducted Harman's one-factor tests of all measurement items in a factor 
analysis without rotation, achieving a solution that accounted for $57.2 \%$ of the total variance. The test generated five factors, and no dominant factor emerged. The first factor explained only $18.7 \%$ of variance. Because a dominant, single factor did not emerge, common method bias is unlikely to be a concern in our data (Podsakoff \& Organ, 1986).

\section{Construct validity and reliability}

Following Churchill (1979), we tested our measurements in two phases: EFA and CFA. In the processes, we analyzed two types of validity (convergent and discriminant) and one type of reliability (internal consistency).

Phase 1: EFA. We measured three variables by scales: perceived home supportiveness (11 items), perceived industry unfavorableness ( 8 items), and inward internationalization ( 8 items). We conducted the EFA using principal component analysis (PCA) with Varimax rotation. The initial exploratory PCA on the 27 items resulted in an unstable six-factor solution explaining $66 \%$ of the variance in the data. To identify the strongest items and eliminate those that performed poorly, we used two statistical criteria as cut-offs for item reduction: low factor loadings $(<0.5)$ and items loading moderately to highly $(>0.4)$ on multiple factors. This stepwise item reduction technique resulted in a final 12 -item pool in a stable threefactor model, explaining about $64 \%$ of the total variance. The final EFA result offered very strong support for both convergent and discriminant validity, with all factor loadings exceeding 0.5 (see Table 2). The internal consistency coefficients (Cronbach's $\alpha$ ) were satisfactory for the three scales. The Cronbach's $\alpha$ values for perceived government supportiveness and inward internationalization were 0.922 and 0.839 , respectively. Perceived industry unfavorableness had a relatively low Cronbach's $\alpha(0.611)$, which also 
met the cut-off (0.600).

-Insert Table 2 about Here-

Phase 2: CFA. We conducted CFA using LISREL 8.7 on the 12-item measures of three variables we derived from EFA (Table 3$)$. The measurement model fit the data satisfactorily $\left(\chi^{2} / \mathrm{df}<1\right.$, goodnessof-fit index $[\mathrm{GFI}]=0.95$, confirmatory fit index $[\mathrm{CFI}]=0.99$, incremental fit index $[\mathrm{IFI}]=0.99$, root mean squared error of approximation $[$ RMSEA] $=0.037$ ), and all factor loadings were highly significant ( $p<0.001$ ), indicating the unidimensionality of the measures (Anderson \& Gerbing, 1988). The composite reliabilities of perceived government supportiveness and inward internationalization were 0.92 and 0.85 , respectively, and perceived industry unfavorableness was 0.65 . Thus, these measures demonstrated adequate construct validity and reliability. We also calculated the average variance extracted (AVE); the AVE of each construct was much higher than its highest shared variance with other constructs, in support of discriminant validity.

----------Insert Table 3 about Here----------

\section{RESULTS}

Tables 4 and 5 present the descriptive statistics, correlations, and regression results. As expected, OFDI is positively correlated with perceived government supportiveness on OFDI and perceived industry unfavorableness. The variance inflation index for the regression models does not exceed 2.0, indicating no concerns about multicollinearity.

-Insert Tables 4 and 5 about here

Hypothesis 1 predicted a positive effect of perceived government supportiveness on the degree of 
OFDI. As shown in Table 5 (Model 1), the supportiveness of the home country government on OFDI has a positive effect on the degree of OFDI $(\beta=0.183, p<0.01)$, so this hypothesis is confirmed. In Hypothesis 2, we predicted a positive relationship between perceived industry unfavorableness and degree of OFDI; in support of this prediction, the coefficient on industry unfavorableness is positive and significant $(\beta=0.128, p<0.1)$. We also compared the coefficients of supportiveness and unfavorableness to check whether there was a significant difference in their effects (Hypothesis 3). A Wald test (F (2,186) $=4.78 * *)$ identifies a statistical difference between the coefficients of supportiveness and unfavorableness for all models in Table 5, in support of Hypothesis 3.

Among the moderating effects, we proposed that a firm's export experience positively moderates relationships between perceived government supportiveness and degree of OFDI and between perceived industry unfavorableness and degree of OFDI. Models 2 and 3 in Table 5 show the interactions of both factors with export intensity and export years, respectively. In the full model (Model 5), the interaction of export intensity and perceived government supportiveness has a positive effect on OFDI $(\beta=0.129, p<$ 0.05), in support of Hypothesis 4a, and the interaction between export years and perceived government supportiveness also is positively significant $(\beta=0.207, p<0.01)$. The interaction between export intensity and perceived industry unfavorableness has a positive effect on OFDI $(\beta=0.224, p<0.01)$, as we predicted in Hypothesis 4b, though the interaction between export years and perceived industry unfavorableness is not significant $(\beta=0.019, p>0.1)$, such that we cannot confirm Hypothesis $4 \mathrm{~b}$ when we measure export experience using export years.

In Hypotheses 5a and 5b, we predicted that a firm's inward internationalization negatively 
moderates the relationships between perceived government supportiveness/industry unfavorableness and degree of OFDI. Model 4 of Table 5 shows these interactions; the full Model 5 in turn reveals that the interaction between inward internationalization and perceived government supportiveness is negative and significant $(\beta=-0.166, p<0.05)$, in support of Hypothesis 5a. However, the interaction between inward internationalization and perceived industry unfavorableness conflicts with our prediction and is marginally significant $(\beta=0.116, p<0.1)$. Hypothesis $5 b$ thus is not supported.

To facilitate understanding of the moderating hypotheses, we plotted the interaction effects in Figures 2-5. Figure 2 shows that the positive effect of perceived government supportiveness on OFDI is stronger for firms with high levels of export intensity. Figure 3 reveals the positive interaction effect of export intensity and unfavorableness of domestic environment on OFDI; the positive effect of unfavorableness is stronger for firms with higher levels of export intensity. Figure 4 shows that the positive effect of perceived government supportiveness on OFDI is stronger for firms with many, rather than fewer, export years. Figure 5 depicts the negative interaction between supportiveness and inward internationalization; consistent with our hypothesis, as the degree of inward internationalization increases from low to high, the effect of supportiveness on OFDI decreases.

----------Insert Figures 2 to 5 about here----------

\section{Additional tests}

Causality. The explanatory variables were measured by asking about perceived government supportiveness/industry unfavorableness in the firms' overall past OFDI activities; while the dependent variables were measured by using information from firms' 2010 annual reports. We predicted a causal 
relationship between environmental factors and OFDI, but this causality might be reversed, such that OFDI may be an antecedent of perceptions of supportiveness and unfavorableness. As Wong and Law (1999: 71) suggest, "Although the true effects may be longitudinal between some management constructs, it is not always possible for researchers to have data that match the exact time duration of the cross-lagged effects." Non-recursive structure equation modeling (SEM) can test reciprocal relationships between two constructs using cross-sectional data (Wong \& Law, 1999), so we applied it, with links from perceived government supportiveness and industry unfavorableness to OFDI, and from OFDI to perceived government supportiveness and industry unfavorableness. Perceived government supportiveness $(\beta=0.13$, $p<0.05)$ and industry unfavorableness $(\beta=0.12, p<0.05)$ positively affect OFDI, but OFDI does not affect perceived government supportiveness $(\beta=0.039, p>0.999)$ or industry unfavorableness $(\beta=0.028$, $p>0.999)$. These results are in line with our theory that perceived government supportiveness and industry unfavorableness affect OFDI.

Sample selection bias. Sample selection bias is a potential methodological issue. Firms with OFDI in our sample may differ substantially from those we excluded due to a lack of foreign sales data, so we may have overestimated the effects of the explanatory variables. Accordingly, we followed the conventional two-stage procedure (Heckman, 1979), as adopted in other studies. In the first stage, for all 333 completed surveys collected, we used firm characteristics to predict the possibility of being selected and to generate the inverse Mill's ratio (IMR), the monotonically decreasing function of the probability that a firm has OFDI. We used probit regression to estimate the possibilities that a firm has OFDI. Based on the results of the first-stage model, we predicted and obtained the IMRs. In the second stage, we 
entered IMR as a regressor to control for selection bias. The results of this two-stage procedure (available on requests) are consistent with our main findings.

Foreign experience of TMTs. The strategic choices a firm makes depend largely on its TMT (Athanassiou \& Nigh, 2000). Foreign experience by TMTs is an important aspect of executives' backgrounds, because it complements and expands the roles of other experiences (Reuber \& Fischer, 1997). It provides firms with international knowledge and experience and helps them develop informational channels and social networks (Nuruzzaman et al., 2017). Such experience and networks are unique resources for firms as they expand internationally. Accordingly, scholars have argued that TMTs with international experience are more likely to lead firms to assume global strategic postures, even if such initiatives come at a significant cost (Singh, Gaur, \& Schmid, 2010; Tihanyi et al., 2000). The results show that TMT foreign experience relates positively to OFDI. We also tested the interactions of TMT foreign experience and perceived supportiveness of home country government, and TMT foreign experience and perceived unfavorableness of the home country industry. However, these results do not show any significant interactions.

\section{DISCUSSION AND CONCLUSION}

In recent years, EMFs have pursued OFDI through acquisitions and other forms. However, literature offers limited insights into the drivers of the OFDI activities of EMFs; it has suggested that home country environments play key roles but not paid much attention to how conditions in home environments might facilitate or constrain firms' OFDI behavior. By drawing on a strategy tripod framework, we develop a theoretical model that combines institution- and industry-based factors to explain the effect of home 
country environment on the OFDI activities of EMFs, and how those activities are conditioned by firm resources such as international experience portfolios. We test our theoretical arguments on data from a sample of 212 Chinese firms, using an extensive survey and archival sources. The results largely support our hypotheses: Both perceived government supportiveness and industry unfavorableness have positive relationships with OFDI, though the effect of perceived government support is stronger than the effect of industry unfavorableness. Export experience positively moderates these relationships; and inward internationalization negatively moderates the effect of supportiveness, but not that of unfavorableness, on OFDI.

Interviews of senior executives validate the hypotheses and the findings of our empirical study.

For example, a senior manager from a large electronics firm in Guangdong province attested to the importance of government support for OFDI:

Governments can do much better and much more at the macro level than an individual firm can do and the perceived support from central and local governments give us confidence and courage to enter the international market.

Other managers and I in our company are less afraid of the barriers in going abroad thanks to the potential resources available from the government such as subsidies and financial supports.

A general manager of an automobile parts manufacturing firm from Suzhou, Jiangsu province, noted: In our acquisition of the target in the U.S., the government helped us in financing and interacting with foreign local authority, and in simplifying the approval process. Also the 
government encouraged us to take the aggressive action to acquire the target in a foreign

country.

With regard to our hypothesis on industry unfavorableness, a general manager of a textile firm from Shangdong province stated:

Establishing factories in less-developed countries largely reduced our production cost and the use of local resource and manpower enhanced our competitive advantage in the global market.

Similarly, the general manager of an automobile parts manufacturing firm in Shenzhen, Guangdong province explained:

Domestic competition is very fierce and we have to seek opportunities in the foreign market. By acquiring foreign firms, we also get their more advanced technology, which can benefit our own research and development; while these technologies, patents, and talents are not available domestically.

With regard to the relative importance of government supportiveness and industry unfavorableness for OFDI, a senior executive of a Shanghai-based chemical product company stated: You know it for sure that China is still a country where government plays a critical role. In the case of our firms' OFDI, and I believe in many cases of other Chinese firms' OFDI as well, government support is definitely more important than the concerns from not-sogood domestic market conditions. The reason is quite straightforward: You are doing your business in this industry, you need to face the competition in China; but when 
government provides strong incentives and resources in such a supportive way, we are more confident to conduct further OFDI projects.

Our research makes several important contributions to theory and practice. First, we provide a coherent theoretical explanation for the OFDI processes of EMFs. Given the importance of local context in EMs, it is important to understand how home environments affect EMFs' international expansion strategies (Luo \& Tung, 2007). We deviate from extant literature, which is focused on ownership-specific advantages as primary drivers of OFDI, by emphasizing the role of the home country environment in determining international expansion of EMFs. Some scholars have argued that home environments of EMs, despite their many weaknesses, are sources of competitive advantage for EMFs (Gaur et al., 2014). However, the phenomenon by which EMFs escape their home countries through OFDI to seek opportunities in foreign markets remains underexplored (Lewin \& Witt, 2007). We focus on the supportiveness of the home environment and unfavorableness of the domestic industry simultaneously to identify the mechanisms whereby these two dimensions affect international expansion. We integrate an institution-based view of international business strategy (Peng et al., 2008) with the industry-based view and combine them with firm internationalization literature.

Second, by including the dimensions of supportiveness and unfavorableness in the same model, we identify their relative strengths in encouraging firms to pursue OFDI. We acknowledge that EMFs enjoy the benefits of home governments that compensate firms for the presence of institutional voids by providing active and passive support. We also acknowledge that EMFs that face difficult conditions in domestic industries internationalize to escape stifling home-industry environments. Mainstream 
internationalization theory focuses on the firm as actor; it pays less attention to the firm's embeddedness in wider society (Child \& Rodrigues, 2005), suggesting the importance of the domestic environment without directly measuring the environment's various dimensions. We overcome these limitations by identifying the relative importance of perceived supportiveness/unfavorableness of the home environment. As countries shift from planned economies to market-based economies, institutional support for marketbased exchanges may become more important, and government support less relevant. However, we argue that in cases of EMs such as China, the government continues to play an important role. Our finding that managerial perceptions of government supportiveness are more important than industry unfavorableness in shaping OFDI activity has consequences for both policy makers who wish to devise policies for encouraging OFDI and practitioners who wish to derive benefits from government policies.

Third, we propose important contingencies that enhance or limit the effect of the home country environment on OFDI. Questions about these contingencies have drawn theoretical interest from IB and management researchers (Edwards, 2010; Ma, Tong, \& Fitza, 2013). By applying an RBV—that is, the third leg of the strategy tripod framework - we propose that export experience and inward internationalization act as key components of international experience portfolios; they condition the effects of perceived home-country government supportiveness and industry unfavorableness on the OFDI activities of EMFs.

Our findings offer important insights to practitioners and policy makers. They suggest that governments should provide credible signals and support for entrepreneurs in emerging economies and that firms should be aware of their governments' various policy initiatives. They also suggest that firms 
should view tough domestic market conditions as pushes to expand abroad rather than mortal threats to their survival. Our findings of interactions between institutions and resources and industry and resources also offer useful implications. For example, home government supportiveness is more likely to foster OFDI in firms that have a high level of exporting activity. In practice, policy makers should pay attention to such firms to promote foreign expansion. We also find that competition pushes firms to escape their unfavorable home industry environments when those firms have high levels of exporting activity. This finding extends prior research on escapism that shows that misalignment between firm strategy and the home country environment leads to international expansion. It also suggests that early-stage exporting activities can help firms escape their constrained home-country environments. Finally, policy makers and practitioners should note our finding that government supportiveness is less important for EMFs with foreign collaborators in their home markets, which act as alternate sources of support.

Despite its contributions, our study has limitations that can be used to direct more research. First, we collected data through survey methods, which limited our sample size. To alleviate concerns about our measures, we employed rigorous methods and tested the reliabilities and validities of our constructs. Although we conducted some interviews after collecting the surveys, additional studies could use more intensive qualitative methods to provide more evidence. Our use of a cross-sectional survey also limited our ability to investigate causality. Because we measured managerial perceptions of the external environment, it is important to consider any changes in TMTs over the period in which firms make OFDI decisions. Additional studies should employ longitudinal designs to address issues of causality and changes in managerial perceptions over time. Second, we studied the influence of government by 
focusing on supportiveness, which, together with firms' own resources and capabilities, influences both the ability and willingness of EMFs to invest in foreign countries (Wang et al, 2012). However, institutional voids related to underdeveloped infrastructure, regulatory systems, or other institutions could impede the OFDI activities of EMFs (Khanna \& Palepu, 1997). Further research could examine both sides simultaneously. For example, one source of support for Chinese firm foreign investment is corresponding foreign investment in support services, such as banking. When banks make international expansion decisions, they follow clients (Qian \& Delios, 2008). Researchers should seek to understand the supportive role of these additional factors.

Third, some of our theorizing is context specific and may not apply to other economies, particularly those in which the state's role is limited. For example, government support may be less important or even meaningless in the developed economies of the West. However, given the economic importance of China and the size of its market, we believe that even a context-specific theory is useful in understanding phenomena that are context specific (Gaur et al., 2013).

Fourth, we examined a limited set of contingency factors that affect the role of the domestic environment on firm strategy. Notably, we did not find any significant moderating effect of TMT experience, even though we uncovered a significant direct effect. It could be the result of our rather crude measure of TMT foreign experience; researchers should examine other contingencies that may enhance or constrain the relationships between home country environments and the OFDI activities of EMFs.

In summary, this research highlights the importance of perceived home country environment conditions for firms' internationalization strategies and identifies important contingencies that affect this 
relationship. Whereas home-country government supportiveness of international expansion encourages EMFs to engage in OFDI by helping them obtain resources and markets, home country industry unfavorableness pushes EMFs to engage in OFDI to escape. Firms' international experience, including export experience and inward internationalization, also moderates the relationship between home country factors and OFDI. We hope this research is a catalyst for developing a more nuanced understanding of the role played by home country environments in the international expansion of EMFs. 


\section{REFERENCES}

Anderson, J. C., \& Gerbing, D. W. 1988. Structural equation modeling in practice: A review and recommended two-step approach. Psychological Bulletin, 103(3): 411.

Ang, S. H., Benischke, M. H., \& Doh, J. P. 2014. The interactions of institutions on foreign market entry mode. Strategic Management Journal, 36(10): 1536-1553.

Athanassiou, N., \& Nigh, D. 2000. Internationalization, tacit knowledge and the top management teams of MNCs. Journal of International Business Studies, 31(3): 471-487.

Barney, J. B. 1991. Firm resources and sustained competitive advantage. Journal of Management, 17(1): 99-121.

Boddewyn, J. J. 1988. Political aspects of MNE theory. Journal of International Business Studies, 18(3): 341-363.

Bhaumik, S. K., Driffield, N., \& Pal, S. 2010. Does ownership structure of emerging-market firms affect their outward FDI? The case of the Indian automotive and pharmaceutical sectors. Journal of International Business Studies,41(3): 437-450.

Birkinshaw, J., Brannen, M., \& Tung, R. 2011. From a distance and generalizable to up close and grounded: Reclaiming a place for qualitative methods in international business research. Journal of International Business Studies, 42(5): 573-581.

Boisot, M., \& Meyer, M.W. 2008. Which way through the open door? Reflections on the internationalization of Chinese firms. Management and Organization Review, 4 (3): 349-365.

Buckley, P. J. 2009. The impact of global factory on economic development. Journal of World Business, 44(2): 131-143.

Buckley, P. J., Clegg, L. J., Cross, A. R., Liu, X., Voss, H., \& Zheng, P. 2007. The determinants of Chinese outward foreign direct investment. Journal of International Business Studies, 38: 499518.

Buckley, P. J., Clegg, J. L., Cross, A. R., \& Voss, H. 2010. What can emerging markets learn from the outward direct investment policies of advanced economies? In K. Sauvant, W. Maschek, \& G. McAllister (Eds.), Foreign direct investment from emerging markets: The challenges ahead. London: Palgrave Macmillan.

Cantwell, J. 2009. Location and the multinational enterprise. Journal of International Business Studies, 40(1): 35-41. 
Castrogiovanni, G. J. 1991. Environmental munificence: A theoretical assessment. Academy of Management Review, 16: 542-563.

Child, J., \& Rodrigues, S. B. 2005. The internationalization of Chinese firms: A case for theoretical extension? Management and Organization Review, 1(3): 381-410.

Churchill, G. A., Jr. 1979. A paradigm for developing better measures of marketing constructs. Journal of Marketing Research, 16(February): 64-73.

Creswell, J. W., \& Clark, V. L. P. 2011. Designing and conducting mixed methods research. John W. Creswell, Vicki L. Plano Clark (2nd ed.). Los Angeles: SAGE Publications.

Cuervo-Cazurra, A. 2012. Extending theory by analyzing developing country multinational companies: Solving the Goldilocks debate. Global Strategy Journal, 2: 153-167.

Cui, L., \& Jiang, F. 2012. State ownership effect on firms' FDI ownership decisions under institutional pressure: A study of Chinese outward-investing firms. Journal of International Business Studies, 43(3): 264-284.

Daft, R. L., \& Weick, K. E. 1984. Toward a model of organizations as interpretation systems. Academy of Management Review, 9(2): 284-295.

Deng, P. 2009. Why do Chinese firms tend to acquire strategic assets in international expansion? Journal of World Business, 44: 74-84.

Dierickx, I, \& Cool, K. 1989. Asset stock accumulation and sustainability of competitive advantage. Management Science, 35(12): 1504-1511.

Dunning, J. H. 1993. Multinational enterprises and the global economy. Wokingham, Berkshire: Addison Wesley.

Economist. 2012. The Visible Hand. http://www.economist.com/node/21542931. Accessed 25 December 2013.

Edwards, J. R. 2010. Reconsidering theoretical progress in organization and management research. Organizational Research Methods, 13(4): 615-619.

Fan, G., Wang, X., \& Zhang, L. 2001. Annual report 2000: Marketization index for China's provinces. China \& World Economy, 5.

Felin, T., Foss, N. J., Heimeriks, K. H., \& Madsen, T. L. 2012. Microfoundations of routines and capabilities: Individuals, processes, and structure. Journal of Management Studies, 49(8): 13511374. 
Gao, G. Y., Murray, J., Kotabe, M., \& Lu, J. 2010. A 'strategy tripod' perspective on export behaviors: Evidence from firms based in an emerging economy. Journal of International Business Studies, 41(3): 377-396.

Gaur, A. S. \& Delios, A. 2015. International diversification of emerging market firms: The role of ownership structure and group affiliation. Management International Review, 55(2): 235-253.

Gaur, A. S., \& Kumar, M. 2018. A systematic approach to conducting review studies: An assessment of content analysis in 25 years of IB research. Journal of World Business, DOI: 10.1016/j.jwb.2017.11.003

Gaur, A. S., Kumar, V., \& Singh, D. 2014. Institutions, resources, and internationalization of emerging economy firms. Journal of World Business, 49(1): 12-20.

Gaur, A. S., \& Lu, J. W. 2007. Ownership strategies and survival of foreign subsidiaries: Impacts of institutional distance and experience. Journal of Management, 33: 84-110.

Gaur, A. S., Malhotra, S., \& Zhu, P. 2013. Acquisition announcements and stock market valuations of acquiring firms' rivals: A test of the growth probability hypothesis in china. Strategic Management Journal, 34(2): 215-232.

Ghemawat, P. 2007. Redefining global strategy. Boston: Harvard Business School Publishing.

Gu, Q., \& Lu, J. W. 2011. Effects of inward investment on outward investment: The venture capital industry worldwide 1985-2007. Journal of International Business Studies, 42(2): 263-284.

Heckman, J. J. 1979. Sample selection bias as a specification error. Econometrica: Journal of the Econometric Society, 153-161.

Hitt, M., Hoskisson, R., \& Kim, H. 1997. International diversification: Effects on innovation and firm performance in product-diversified firms. Academy of Management Journal, 40(4): 767-798.

Hoskisson, R. E., Eden, L., Lau, C. M., \& Wright, M. 2000. Strategy in emerging economies. Academy of Management Journal, 43(3): 249-267.

Johanson, J. \& Vahlne, J. E. 2009. The Uppsala internationalization process model revisited: From liability of foreignness to liability of outsidership. Journal of International Business Studies, 40(9): 1411-1431.

Kang, Y., \& Jiang, F. 2012. FDI location choice of Chinese multinationals in East and Southeast Asia: Traditional economic factors and institutional perspective. Journal of World Business, 47: 45-53.

Kedia, B.L., Mukherjee, D. 2009. Understanding offshoring: A research framework based on disintegration, location and externalization advantages. Journal of World Business, 44 (3): 250- 
261.

Khanna, T., \& Palepu, K. G. 1997. Why focused strategies may be wrong for emerging markets. Harvard Business Review, 75(4): 41-51.

Knight, G. A., \& Cavusgil, S. T. 2004. Innovation, organizational capabilities, and the born-global firm. Journal of International Business Studies, 35(2): 124-141.

Kosova, R. 2010. Do foreign firms crowd out domestic firms? Evidence from the Czech Republic. The Review of Economics and Statistics, 92(4): 861-881.

Lecraw, D. J. 1993. Outward direct investment by Indonesian firms: Motivation and effects. Journal of International Business Studies, 24(3): 589-600.

Lewin, A. Y., \& Witt, M. A. 2007. Outward foreign direct investment as escape response to home country institutional constraints. Journal of International Business Studies, 38(4): 579-594.

Li, J., Li, Y., \& Shapiro, D. 2012. Knowledge seeking and outward FDI of emerging market firms: The moderating effect of inward FDI. Global Strategy Journal, 2(4): 277-295.

Lu, J., Liu, X., Wright, M., \& Filatotchev, I. 2014. International experience and FDI location choices of Chinese firms: The moderating effects of home country government support and host country institutions. Journal of International Business Studies, 45(4): 428-449.

Lu, W. J., \& Ma, X. F. 2008. The contingent value of local partner's business group affiliation. Academy of Management Journal, 51(2): 295-314.

Luo, Y. D. 2005. Transactional characteristics, institutional environment and joint venture contracts. Journal of International Business Studies, 36(2): 209-230.

Luo, Y., \& Tung, R. 2007. International expansion of emerging market enterprises: A springboard perspective. Journal of International Business Studies, 38(4): 481-498.

Luo, Y., \& Tung, R. 2017. A general theory of springboard MNEs. Journal of International Business Studies, https://doi.org/10.1057/s41267-017-0114-8.

Luo, Y., \& Wang, S. L. 2012. Foreign direct investment strategies by developing country multinationals: A diagnostic model for home country effects. Global Strategy Journal, 2(3): 244-261.

Luo, Y., Xue, Q., \& Han, B. 2010. How emerging market governments promote outward FDI: Experience from China. Journal of World Business, 45: 68-79.

Ma, X., Ding, Z., \& Yuan, L. 2016. Subnational institutions, political capital, and the internationalization of entrepreneurial firms in emerging economies. Journal of World Business, 2016 51(5):843-854. 
Ma, X., Tong, T. W., \& Fitza, M. 2013. How much does subnational region matter to foreign subsidiary performance: Evidence from Fortune Global 500 corporations' investment in China. Journal of International Business Studies, 44(1): 66-87.

Makino, S., Lau, C. M., \& Yip, R. S. 2002. Asset-exploitation versus asset-seeking: Implications for location choice of foreign direct investment from newly industrialized economies. Journal of International Business Studies, 33(3): 403-421.

Mathews, J. A. 2006. Dragon multinationals: New players in 21st century globalization. Asia Pacific Journal of Management, 23(1): 5-27.

Mathews, J. A. \& Zander, I. 2007. The international entrepreneurial dynamics of accelerated internationalization. Journal of International Business Studies, 38(3): 387-403.

Mukherjee, D., Gaur, A. S., \& Dutta, A. 2013. Creating value through offshore outsourcing: A resource management framework. Journal of International Management, 19 (4): 377-389.

North, D. C. 1990. Institutions, institutional change and economic performance. Cambridge University Press.

Nuruzzaman, N., Gaur, A. S., \& Sambharya, R. 2017. A microfoundations approach to studying innovation in the multinational subsidiaries. Global Strategy Journal, forthcoming.

Ocasio, W. 1997. Towards an attention-based view of the firm. Strategic Management Journal, 18: 187206.

Peng, M. W., Wang, D. Y. L. \& Jiang, Y. 2008. An institution-based view of international business strategy: A focus on emerging economies. Journal of International Business Studies, 39(5): 920936.

Podsakoff, P. M., \& Organ, D. W. 1986. Self reports in organizational research: Problems and prospects. Journal of Management, 12: 531-544.

Porter, M. E. 1990. The competitive advantage of nation., New York, NY: Free Press.

Qian, L., \& Delios, A. 2008. Internalization and experience: Japanese banks' international expansion, 1980-1998. Journal of International Business Studies, 231-248.

Ramamurti, R. 2012. What is really different about emerging market multinationals? Global Strategy Journal, 2(1): 41-47.

Reuber, A. \& Fischer, E. 1997. The influence of top management team's international experience on international behaviors of SMES. Journal of International Business Studies, 28: 807-825.

Rugman, A. M., \& Verbeke, A. 1992. A note on the transnational solution and the transaction cost theory 
of multinational strategic management. Journal of International Business Studies, 23(4): 761-771.

Rui, H., \& Yip, G. S. 2008. Foreign acquisitions by Chinese firms: A strategic intent perspective. Journal of World Business, 43(2): 213-226.

Sauvant, K. P., \& Chen, H. 2013. A China-US Bilateral Investment Treaty: A Template for a Multilateral Framework for Investment? Transnational Corporations Review, 5(1): 1-3.

Scott, W. R. 2001. Institutions and organizations: Ideas and interests. Sage.

Singh, D. 2009. Export performance of emerging market firms. International Business Review, 18(4): 321-330.

Singh, D., Gaur, A. S., \& Schmid, F. P. 2010. Corporate diversification, TMT experience, and performance. Management International Review, 50: 35-56.

Singh, D., Pattnaik, C., Gaur, A. S., \& Ketencioglu, E. 2018. Corporate expansion during pro-market reforms in emerging markets: The contingent value of group affiliation and unrelated diversification. Journal of Business Research, 82: 220-229.

Sullivan, D. 1994. Measuring the degree of internationalization of a firm. Journal of International Business Studies, 25(2): 325-42.

Tang, F. 2007. China's top 10 mergers and acquisitions revealed. http://www.china.org.cn/english/BAT/195761.htm. Accessed 11 January 2015.

Tihanyi, L., Ellstrand, A. E., Daily, C. M., \& Dalton, D. R. 2000. Composition of the top management team and firm international diversification. Journal of Management, 26(6): 1157-1177.

UNCTAD. 2015. World investment report 2015: Global value chains: Investment and trade for development. New York and Geneva: United Nations Publications.

Voss, H., Buckley, P. J., \& Cross, A. R. 2010. The impact of home country institutional effects on internationalization. Multinational Business Review, 18(3): 25-48.

Wan, W. P., \& Hoskisson, R. E. 2003. Home country environments, corporate diversification strategies, and firm performance. Academy of Management Journal, 46(1): 27-45.

Wang, C., Hong, J., Kafouros, M., \& Wright, M. 2012. Exploring the role of government involvement in outward FDI from emerging economies. Journal of International Business Studies, 43(7): 655676.

Weick, K. 1979. The social psychology of organizing, $2^{\text {nd }}$ Edition. Reading, Mass.: Addison-Wesley Pub.

Welch, L. S., \& Luostarinen, R. 1993. Inward-outward connections in internationalization. Journal of 
International Marketing, 1(1): 44-56.

Wiersema, M. F., \& Bowen., H. P. 2008. Corporate international diversification: The impact of foreign competition, industry globalization and firm diversification. Strategic Management Journal, 22: $115-132$.

Wong, C. S., \& Law, K. S. 1999. Testing reciprocal relations by nonrecursive structural equation models using cross- sectional data. Organizational Research Methods, 2(1): 69-87.

Xia, J., Ma, X., Lu, J. W., \& Yiu, D. W. 2014. Outward foreign direct investment by emerging market firms: A resource dependence logic. Strategic Management Journal, 35(9): 1343-1363.

Yiu, D. W., Lau, C. M., \& Bruton, G. 2007. International venturing by emerging economy firms: The effects of firm capabilities, home country networks, and corporate entrepreneurship. Journal of International Business Studies, 38: 519-540.

Yu, J., Engleman, R. M., \& Van de Ven, A. H. 2005. The integration journey: An attention-based view of the merger and acquisition integration process. Organization Studies, 26(10): 1501-1528.

Zhou, K. Z., Yim, C. K., \& Tse, D. K. 2005. The effects of strategic orientations on technology-and market-based breakthrough innovations. Journal of Marketing, 69(2): 42-60.

Zhou, L., Wu, W. P., \& Luo, X. 2007. Internationalization and the performance of born-global SMEs: The mediating role of social networks. Journal of International Business Studies, 38(4): 673-690. 
Table 1

Empirical research on OFDIs of EMFs

\begin{tabular}{|c|c|c|}
\hline Authors & Setting & Important findings \\
\hline $\begin{array}{l}\text { Ang, } \\
\text { Benischke \& } \\
\text { Doh (2014) }\end{array}$ & $\begin{array}{l}\text { MNCs from the manufacturing sector of six } \\
\text { emerging economies over the period 1995- } \\
2008\end{array}$ & $\begin{array}{l}\text { EM MNCs mimic local firms when they make market entry choices; regulatory distance } \\
\text { serves as a moderating effect. }\end{array}$ \\
\hline $\begin{array}{l}\text { Bhaumik, } \\
\text { Driffield, \& } \\
\text { Pal (2010) } \\
\end{array}$ & $\begin{array}{l}\text { Indian pharmaceutical and automotive } \\
\text { sectors from } 2000-2006\end{array}$ & $\begin{array}{l}\text { Ownership structures of emerging-market firms, which are shaped by local institutions, } \\
\text { influence decisions to undertake OFDI. }\end{array}$ \\
\hline $\begin{array}{l}\text { Buckley et al. } \\
(2007)\end{array}$ & $\begin{array}{l}\text { OFDI by Chinese multinational enterprises } \\
\text { (MNEs) over the period 1984-2001 }\end{array}$ & $\begin{array}{l}\text { OFDI is a strategy to respond to firm-level factor and home country institutional } \\
\text { environments. }\end{array}$ \\
\hline $\begin{array}{l}\text { Cui and Jiang } \\
\text { (2012) }\end{array}$ & $\begin{array}{l}132 \text { FDI entries made by Chinese firms from } \\
2000-2006\end{array}$ & $\begin{array}{l}\text { Home regulatory, host regulatory, and host normative institutions are the three main } \\
\text { external institutions influencing the FDI strategic decisions of firms. }\end{array}$ \\
\hline Lecraw (1993) & $\begin{array}{l}\text { Indonesian firms in } 24 \text { industries from 1986- } \\
1990\end{array}$ & $\begin{array}{l}\text { Indonesian multinationals have gone abroad not only to exploit their ownership advantages } \\
\text { but also to access and develop ownership advantages they did not previously possess. }\end{array}$ \\
\hline $\begin{array}{l}\mathrm{Li}, \mathrm{Li}, \& \\
\text { Shapiro } \\
\text { (2012) }\end{array}$ & $\begin{array}{l}\text { Chinese manufacturing firms from } 1990- \\
2009 .\end{array}$ & $\begin{array}{l}\text { A host country's industry-specific technology advantage increases OFDI from EMFs; } \\
\text { inward FDI decreases OFDI from EMFs. }\end{array}$ \\
\hline $\begin{array}{l}\text { Luo and Wang } \\
\text { (2012) }\end{array}$ & $\begin{array}{l}\text { Chinese firms that engaged in OFDI (survey } \\
\text { in 2008-2009) }\end{array}$ & OFDI is a strategy to react to both home country operational and environmental influences. \\
\hline $\begin{array}{l}\text { Wang, Hong, } \\
\text { Kafouros, \& } \\
\text { Wright (2012) }\end{array}$ & All Chinese-firm OFDI from 2006-2007 & Government involvement and a firm's own resources and capabilities influence OFDI. \\
\hline $\begin{array}{l}\text { Xia et al. } \\
(2014)\end{array}$ & $\begin{array}{l}\text { Chinese public manufacturing firms from } \\
\text { 2001-2007 }\end{array}$ & EMF-foreign firm interdependence affects OFDI by EMFs. \\
\hline $\begin{array}{l}\text { Yiu, Lau, \& } \\
\text { Bruton (2007) }\end{array}$ & Chinese from all industries in 2003 and 2004 & OFDI is a strategy to respond to ownership advantages and institutional characteristics. \\
\hline
\end{tabular}


Table 2

Results of exploratory factor analysis (EFA)

\begin{tabular}{|c|c|c|c|c|}
\hline Items & Contexts & \multicolumn{3}{|c|}{ EFA } \\
\hline \multicolumn{5}{|c|}{$\begin{array}{l}\text { Supportiveness: Extent of helpfulness of government promoting OFDI policies } \\
\text { for your firm }\end{array}$} \\
\hline HIS1 & Foreign-rights-and-interests-guaranteeing policy & .918 & -.073 & .030 \\
\hline HIS2 & Approval-and-commodity-inspection-simplifying policy & .894 & .047 & -0.002 \\
\hline HIS3 & Foreign-exchange-supporting policy & .894 & .083 & -.013 \\
\hline HIS4 & Foreign-investment information services & .893 & -.022 & .033 \\
\hline \multicolumn{5}{|c|}{$\begin{array}{l}\text { Inward internationalization: Compared to other firms in same industry, how } \\
\text { much is your firm involved in foreign business in your home country? }\end{array}$} \\
\hline IFDI1 & Utilized advanced and new technology from foreign country & 0.138 & .812 & .048 \\
\hline IFDI2 & Utilized foreign capital (including joint venture) & -0.059 & .790 & 0.145 \\
\hline IFDI3 & $\begin{array}{l}\text { Built a joint-ownership firm with foreign company in domestic } \\
\text { country }\end{array}$ & -.075 & .764 & .260 \\
\hline IFDI4 & Utilized production line and devices from foreign country & .028 & 671 & .103 \\
\hline \multicolumn{5}{|c|}{$\begin{array}{l}\text { Unfavorableness: How do you evaluate your firm's competition environment in } \\
\text { your home country? }\end{array}$} \\
\hline DC1 & Extent of availability of high-level talent in home country & .048 & -.039 & .848 \\
\hline DC2 & $\begin{array}{l}\text { Extent of availability of advanced technology and technology } \\
\text { resources in home country }\end{array}$ & .108 & .126 & .745 \\
\hline DC3 & Competition from foreign MNEs in home country & -.080 & .237 & .571 \\
\hline DC4 & Competition from domestic firms in home country & -.021 & .162 & .538 \\
\hline \multicolumn{2}{|c|}{ Variance explained: $64.28 \%$} & $27.60 \%$ & $24.38 \%$ & $12.30 \%$ \\
\hline \multicolumn{2}{|c|}{ Cronbach's $\alpha$} & 0.922 & 0.839 & 0.611 \\
\hline
\end{tabular}

Table 3

Results of confirmatory factor analysis (CFA)

\begin{tabular}{lllll}
\hline Variables & Items & Factor loading & AVE & CR \\
\hline Supportiveness & HIS1 & 0.92 & 0.7253 & 0.9132 \\
& HIS2 & 0.79 & & \\
& HIS3 & 0.81 & & 0.7531 \\
Unfavorableness & HIS4 & 0.88 & 0.4546 & \\
& DC1 & 0.55 & & 0.7741 \\
& DC2 & 0.98 & & \\
Inward Internationalization & DC3 & 0.57 & & \\
& DC4 & 0.48 & & \\
& IFDI1 & 0.7042 & & \\
\hline
\end{tabular}

$\mathrm{df}=47, \mathrm{GFI}=0.95, \mathrm{CFI}=0.99, \mathrm{IFI}=0.99, \mathrm{RMSEA}=0.037$ 
Table 4

Descriptive statistics and correlations $a, b$

\begin{tabular}{|c|c|c|c|c|c|c|c|c|c|c|c|c|c|c|c|c|c|c|}
\hline & Mean & S.D. & 1 & 2 & 3 & 4 & 5 & 6 & 7 & 8 & 9 & 10 & 11 & 12 & 13 & 14 & 15 & 16 \\
\hline 1.Firm Age (ln) & 2.639 & 0.687 & & & & & & & & & & & & & & & & \\
\hline 2.Firm Size (ln) & 6.614 & 2.236 & 0.416 & & & & & & & & & & & & & & & \\
\hline 3.Performance & 4.835 & 1.235 & 0.150 & 0.284 & & & & & & & & & & & & & & \\
\hline $\begin{array}{l}\text { 5.TMT Foreign } \\
\text { Experience }\end{array}$ & 0.476 & 0.500 & 0.059 & 0.148 & 0.169 & 0.267 & & & & & & & & & & & & \\
\hline $\begin{array}{l}\text { 6.Technological } \\
\text { Capability }\end{array}$ & 4.097 & 1.356 & -0.005 & -0.107 & 0.169 & -0.029 & -0.004 & & & & & & & & & & & \\
\hline $\begin{array}{l}\text { 7. Foreign } \\
\text { government support }\end{array}$ & 4.767 & 1.256 & 0.035 & 0.113 & 0.028 & 0.007 & 0.201 & -0.043 & & & & & & & & & & \\
\hline 8. Localization & 4.569 & 1.006 & 0.049 & 0.040 & 0.236 & -0.101 & 0.110 & 0.085 & 0.267 & & & & & & & & & \\
\hline 9. Regional & 9.421 & 0.382 & 0.109 & -0.036 & -0.042 & -0.083 & -0.082 & -0.052 & 0.026 & 0.025 & & & & & & & & \\
\hline Protection & & & & & & & & & & & & & & & & & & \\
\hline $\begin{array}{l}\text { 10. Regional } \\
\text { Average Wage }\end{array}$ & $\begin{array}{l}3287 \\
4.120\end{array}$ & 6844.217 & 0.096 & 0.373 & 0.001 & 0.155 & 0.015 & -0.127 & 0.110 & -0.043 & -0.315 & & & & & & & \\
\hline $\begin{array}{l}\text { 11. Industrial } \\
\text { Support }\end{array}$ & 0.700 & 0.353 & 0.000 & 0.276 & 0.064 & -0.349 & 0.121 & 0.069 & 0.027 & 0.190 & 0.095 & 0.010 & & & & & & \\
\hline $\begin{array}{l}\text { 13.Unfavorableness } \\
c\end{array}$ & 4.839 & 0.834 & 0.011 & 0.109 & 0.157 & 0.052 & 0.041 & 0.185 & -0.048 & 0.162 & 0.033 & -0.007 & 0.224 & 0.009 & & & & \\
\hline 14.Export Intensity & 0.53 & 0.309 & -0.215 & -0.333 & -0.334 & -0.081 & -0.108 & 0.027 & 0.038 & 0.028 & -0.032 & -0.073 & -0.043 & -0.073 & -0.079 & & & \\
\hline 15.Export Year $(\ln )$ & 2.15 & 0.678 & 0.488 & 0.282 & -0.036 & 0.201 & 0.056 & -0.127 & -0.061 & 0.01 & -0.034 & 0.157 & 0.042 & -0.051 & 0.099 & 0.083 & & \\
\hline $\begin{array}{l}\text { 16. Inward } \\
\text { Internationalization }\end{array}$ & 3.269 & 1.255 & 0.144 & 0.195 & 0.045 & -0.070 & 0.082 & 0.183 & 0.092 & 0.203 & 0.106 & -0.064 & 0.205 & 0.003 & 0.329 & -0.017 & 0.069 & \\
\hline $\begin{array}{l}\text { 17. OFDI } \\
0.052\end{array}$ & 0.346 & 0.286 & 0.112 & 0.123 & 0.052 & 0.252 & -0.040 & -0.008 & 0.133 & -0.122 & 0.083 & 0.063 & 0.170 & 0.149 & 0.099 & 0.164 & 0.066 & 0.265 \\
\hline
\end{tabular}


Table 5

Results of regression for OFDI

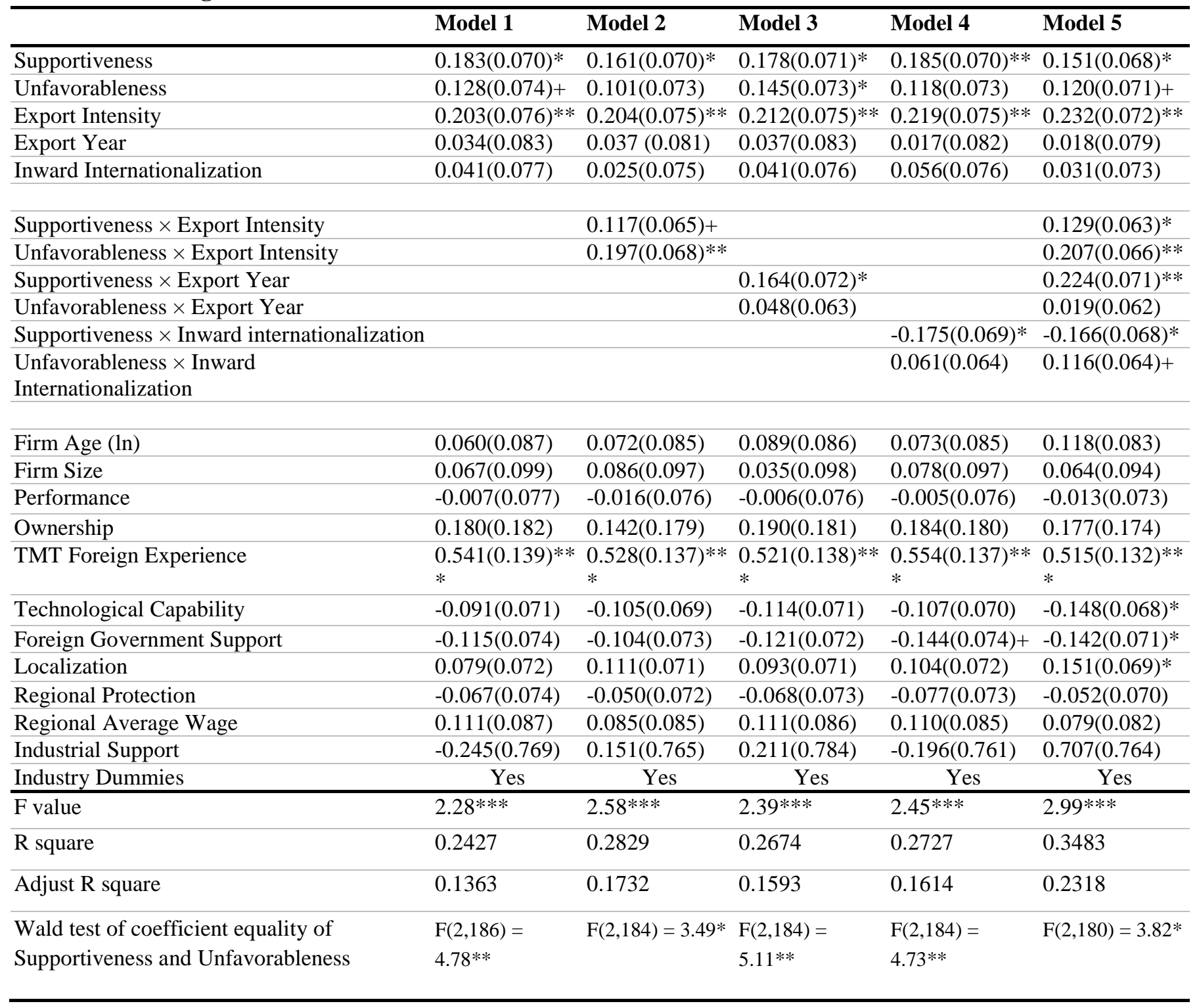

Note: $\mathrm{N}=212$. Supportiveness refers to perceived home-country government supportiveness. Unfavorableness refers to perceived home-country industry unfavorableness.

${ }^{+} p<0.10 ; * p<0.05 ; * * \mathrm{p}<0.01 ; * * * p<0.001$ 
Figure 1. Conceptual model

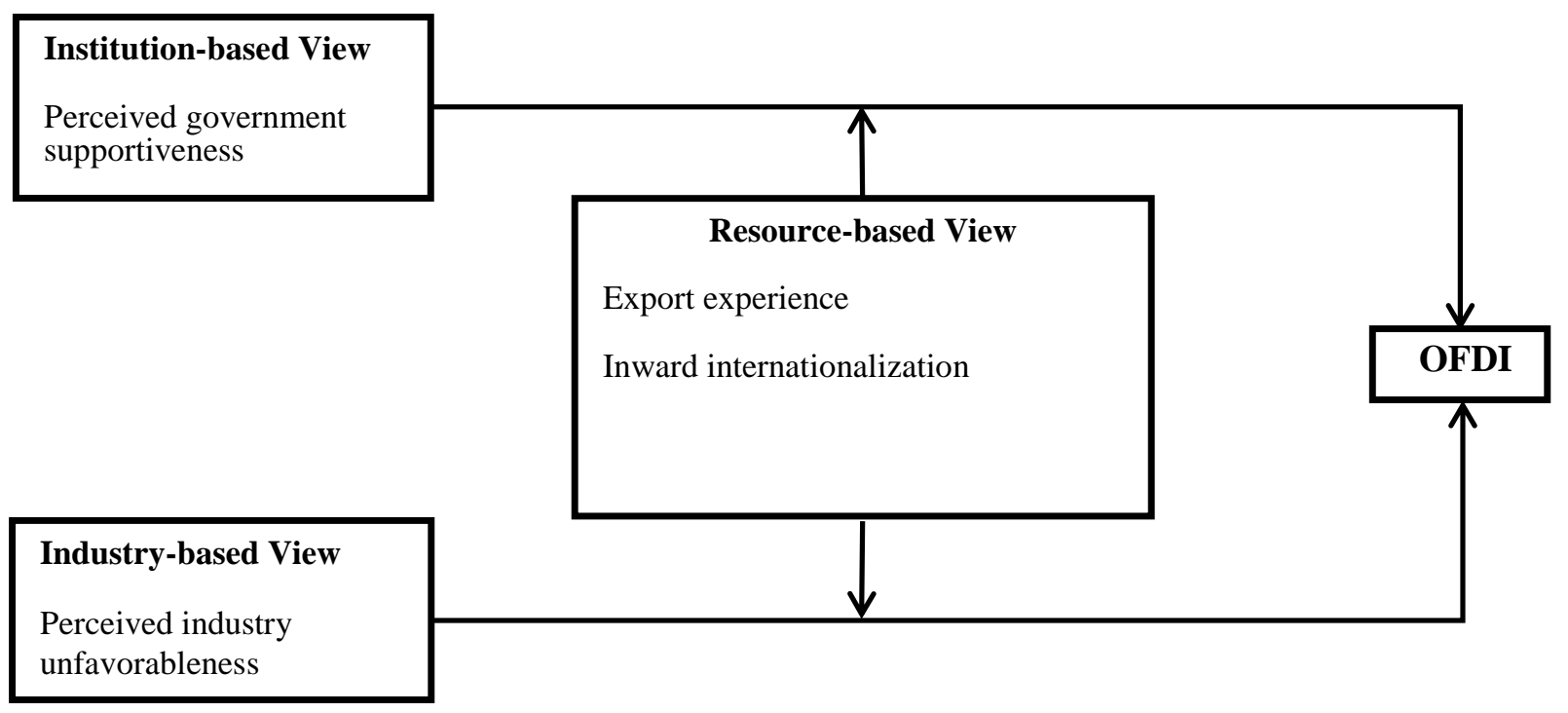

Figure 2:

Export intensity as a moderator between perceived government supportiveness and OFDI

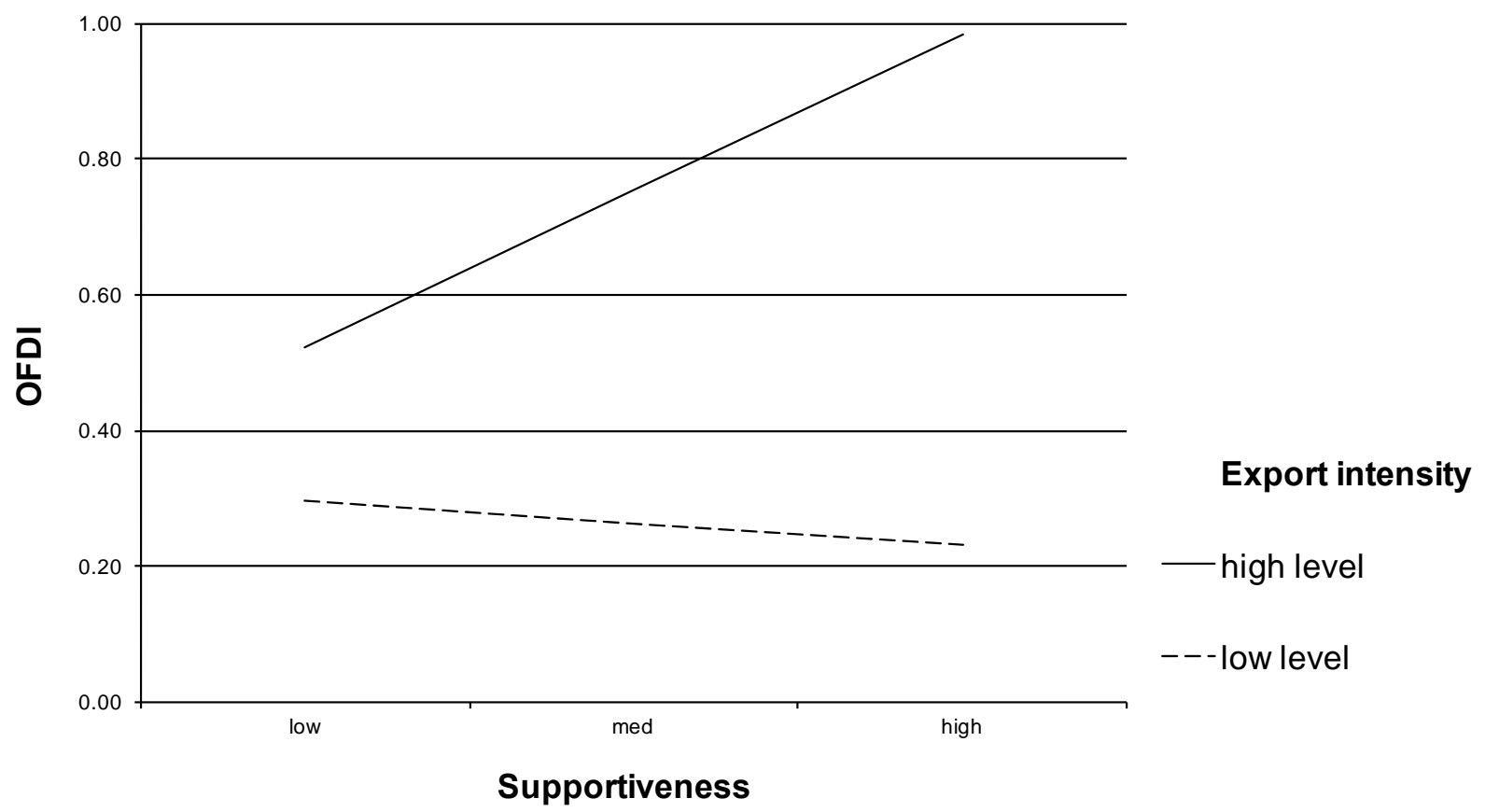


Figure 3:

Export intensity as a moderator between perceived industry unfavorableness and OFDI

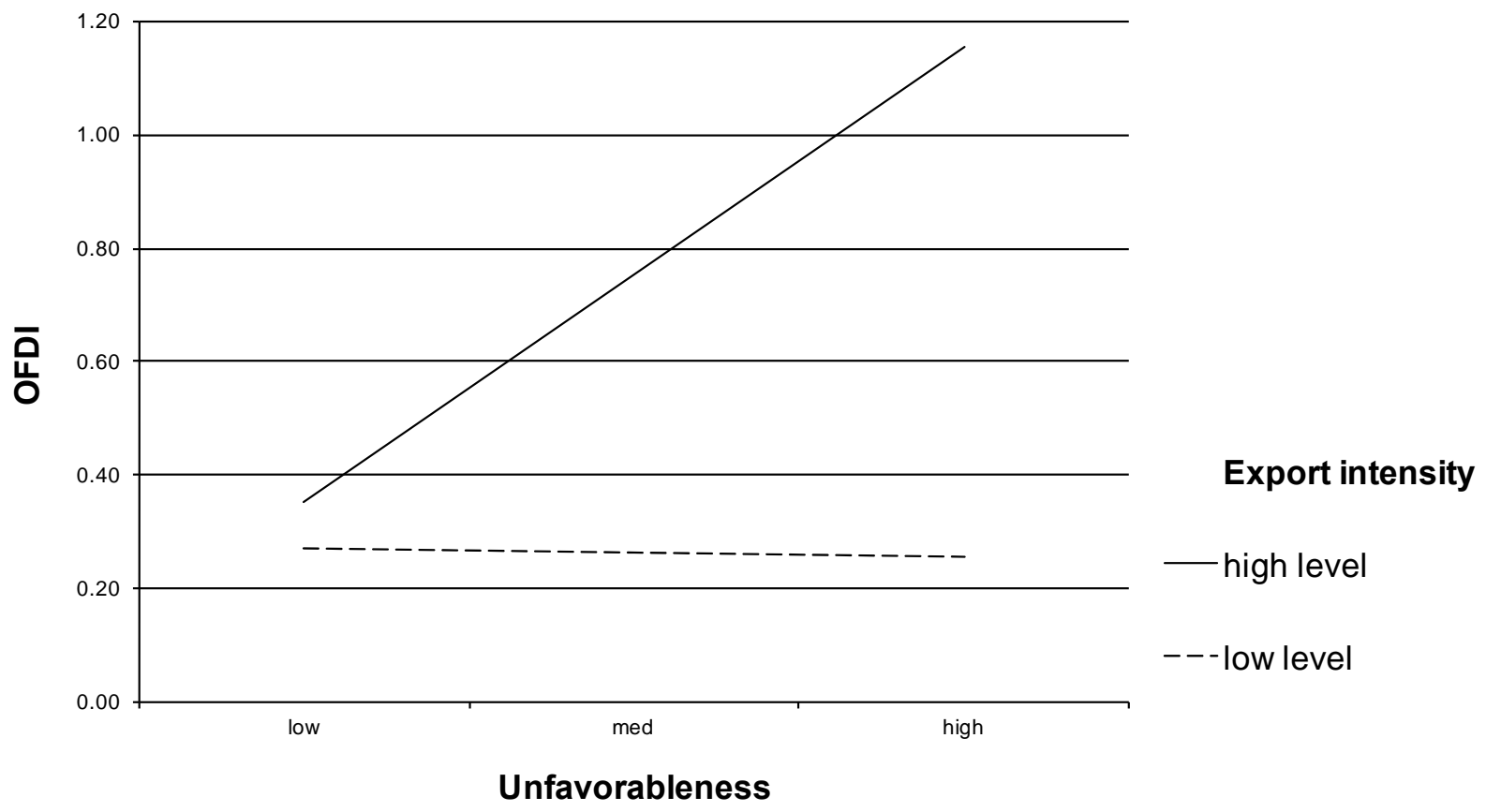

Figure 4:

Export years as a moderator between perceived government supportiveness and OFDI 


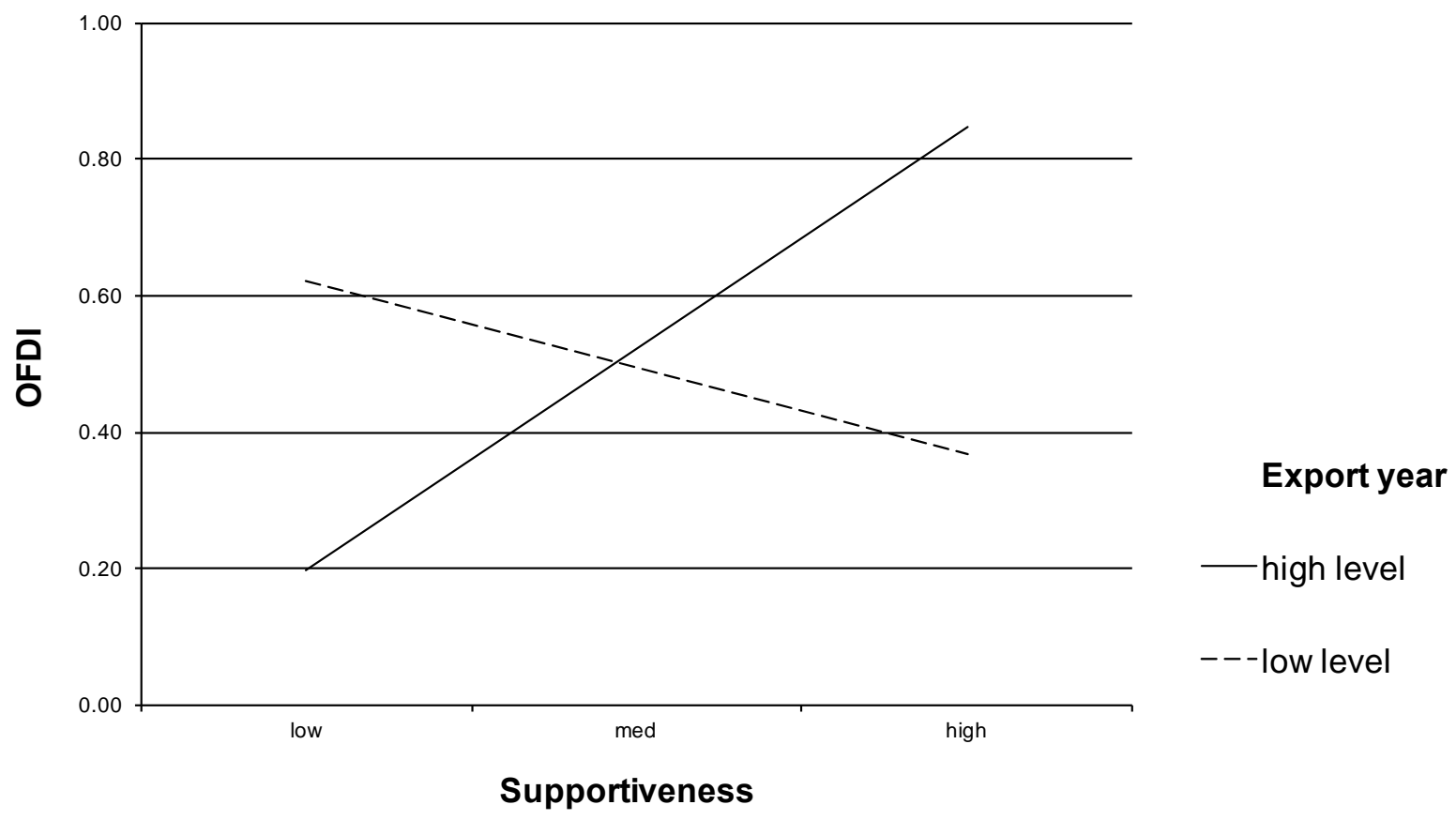

Figure 5:

Inward internationalization as a moderator between perceived government supportiveness and OFDI

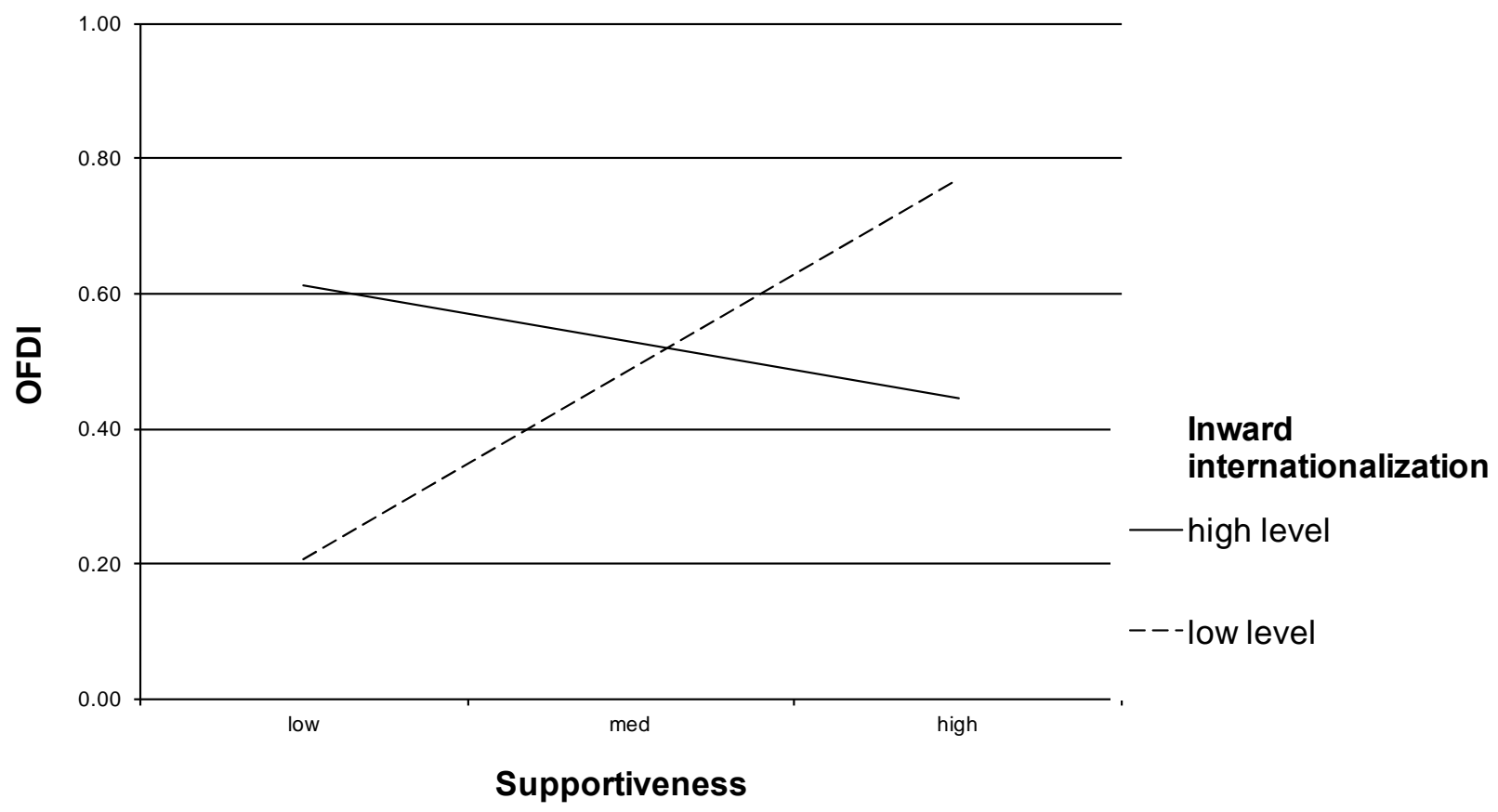

